ФОРМУВАННЯ КОМПОНЕНТІВ ТВОРЧОЇ ДІЯЛЬНОСТІ У МАЙБУТНІХ ФАХІВЦІВ З ФІЗИЧНОЇ КУЛЬТУРИ І СПОРТУ

\title{
FORMATION OF COMPONENTS OF CREATIVE ACTIVITY IN FUTURE SPECIALISTS IN PHYSICAL CULTURE AND SPORT
}

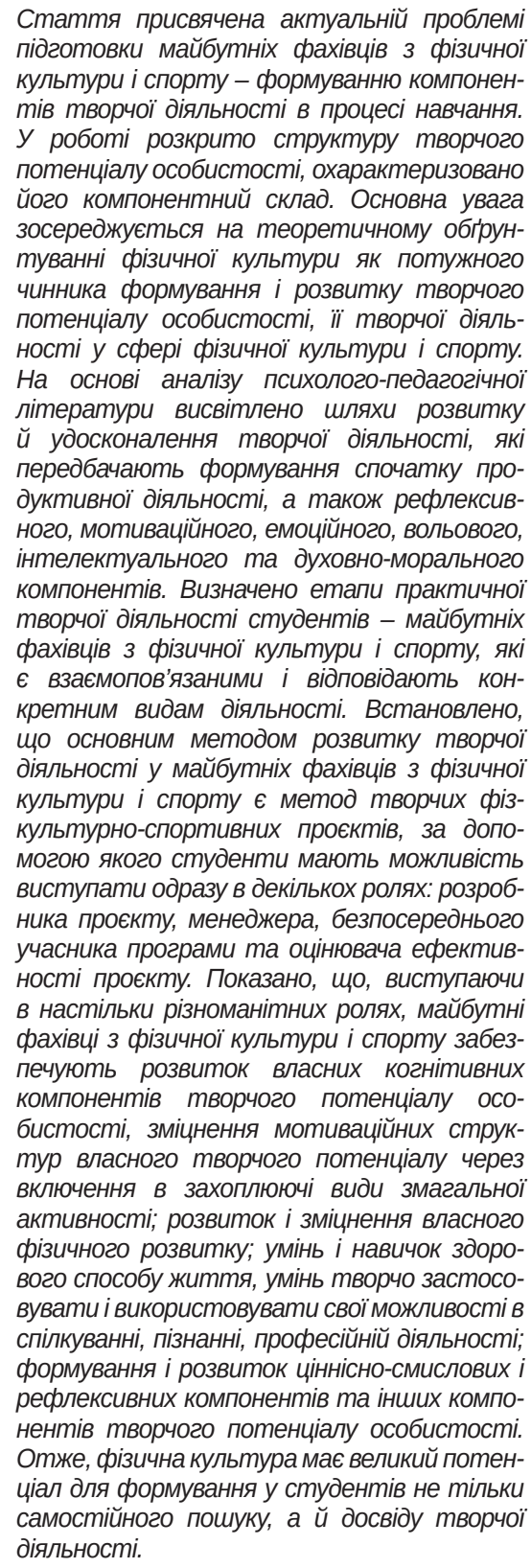

Стаття присвячена актуальній проблемі есі навчання. У роботі розкрито структуру творчого потенціалу особистості, охарактеризовано його компонентний склад. Основна увага обгрунрозвитку творчого потенціалу особистості, їі творчої діяльс сорері фозичної культури і спорту. HOCmi, які передбачають формування спочатку про(1) інтелектуального та духовно-морального компонентів. Визначено етапи практичної - майбуmніх фрахівців з фрізичної культури і спорту, які $\epsilon$ взаємопов'язаними і відповідають конщо основним методом розвитку творчої діяльності у майбутніх фрахівців з фрізичної культури і спорту є метод творчих фрізмоль виступати одразу в декількох ролях: розробника проєкту, менеджера, безпосереднього учасника програми та оцінювача есектив-

УДК 796.01+ 79-053.67

DOI https://doi.org/10.32843/2663-60852019-13-2-22

\section{Подгорна В.В.,}

канд. пед. наук, старший викладач кафредри теорії і методики фрізичної культури та спортивних дисциплін Південноукраїнського національного педагогічного університету

імені К.Д. Ушинського

\section{Дроздова К.В.,}

канд. пед. наук, старший викладач кафедри теорії і методики фрізичної культури та спортивних дисциплін Південноукраїнського національного педагогічного університету імені К.Д. Ушинського
Ключові слова: творчий потенціал, творча діяльність, фрізична культура, майбутні фрахівці з фрізичної культури і спорту.

The article is devoted to the actual problem of training future specialists in physical culture and sports - the formation of components of creative activity in the process of learning. The article shows the structure of the creative potential of the personality, describes its component composition. The main focus is on the theoretical substantiation of physical culture as a powerful factor in the formation and development of creative potential of the individual, creative activity in the field of physical culture and sports. On the basis of the analysis of psychological and pedagogical literature, the ways of development and improvement of creative activity were established. This involves the formation of a productive activity, as well as reflexive, motivational, emotional, volitional, intellectual and spiritual-moral components. The stages of practical creative activity of students future specialists in physical culture and sports are determined. It is interconnected and corresponds to specific activities. It is established that the main method of development of creative activity of future specialists in physical culture and sports is the method of creative sports and sports projects. With this method students have the opportunity to act simultaneously in several roles: the project developer, the manager, the direct participant of the program and the evaluator of the effectiveness of the project. The article shows that speaking up in such diverse roles, future specialists in physical culture and sports provide the development of their own cognitive components of creative potential of the individual. They have the opportunity to strengthen the motivational structures of their own creativity through inclusion in exciting kinds of competitive activity. There is development and strengthening of own physical development; skills and abilities of a healthy way of life, skills to apply creatively and use their possibilities in communication, knowledge, professional activity. Provides formation and development of value-semantic and reflexive components and other components of the creative potential of the individual.

Key words: creative potential, creative activity, physical culture, future specialists in physical culture and sports.
Постановка проблеми у загальному вигляді та її зв'язок з важливими науковими чи практичними завданнями. На новому етапі реформування системи освіти навчальний процес переорієнтовано на виховання творчої особистості, підготовленої до ефективної життєдіяльності в умовах складної сучасної соціально-економічної ситуації. Це передбачає перехід до нових педагогічних технологій і сучасних методів освіти. Теорія і практика фрізичного виховання ще не володіють обґрунтованими методичними рішеннями, спрямованими на розвиток творчих здібностей у студентів ЗВО на заняттях з фрізичної культури, інтегративного прояву розумових і рухових здібностей. Процес формування суб'єктивної творчості на заняттях фрізичної культури залишається маловивченим.

Дослідження виконано в межах наукової теми кафедри теорії та методики фрізичної культури та спортивних дисциплін Державного закладу «Південноукраїнський національний педагогічний університет імені К.Д. Ушинського» «Теоретикометодичні засади підготовки майбутніх учителів 
фрізичної культури до фрізкультурно-оздоровчої, спортивно-масової та здоров'язбережувальної профресійної діяльності зі студентами ВНЗ» (протокол № 5 від 26 грудня 2013 р.).

Аналіз останніх досліджень і публікацій 3 проблеми виховання творчої особистості дав змогу визначити різні концептуальні наукові позиції, які перебувають у прямій залежності від того, який 3 аспектів виходить на перший план: середовище, в якому здійснюється творчість [6], творчий продукт [8], творчий процес [12], творча особистість [4], творча активність [13] тощо. Автори збігаються в думці, що продуктивність мислення, яка притаманна творчій діяльності, передбачає гнучкість і евристичність у пошуку рішення задачі, 3 якою раніше індивід не зустрічався, здатність знаходити нові взаємозв'язки між об'єктами і проводити аналогії, швидко і доцільно перетворювати необхідну інфрормацію.

У фрілософрських концепціях фрізичної культури і спорту визначається, що місце фрізичної культури в системі культурних цінностей суспільства відповідає її значенню як найважливішого чинника прогресу і досягнення високого рівня культури життя людей $[1 ; 3]$. Культура, таким чином, виявляється вираженням специфічної людської єдності з природою і суспільством, своєрідним критерієм рівня розвитку творчих сил і здібностей особистості. Окрім матеріалізованих, предметних результатів діяльності людей, культура включає і особистісні, індивідуальні людські сили і здібності, реалізовані в діяльності [2; 4].

Єдність рефлексивного, мотиваційного, пізнавального, емоційного, комунікативного, духовно-морального і вольового компонентів структури особистості є основою творчої діяльності, яка являє собою вид спеціалізованої діяльності, зумовлений органічним злиттям пізнавальної, ціннісно-орієнтаційної та перетворювальної, що забезпечує інтенсивний розвиток уяви, емоційної сорери, образної пам'яті, мови і мислення та інших сторін цілісної особистості [4].

Автори вважають, що творчість у руховій сорері людини доцільно розвивати в тих видах діяльності, якими вона безпосередньо займається, тому фрормування творчих здібностей майбутніх фрахівців 3 фрізичної культури і спорту має відбуватися в конкретних видах їхньої рухової активності [2; 5; 11].

Виділення не вирішених раніше частин загальної проблеми. Проведений аналіз теорії і практики фрізичного виховання дав змогу виявити протиріччя між наявною потребою у формуванні творчих здібностей студентів на заняттях з фрізичної культури та відсутністю методичних рішень щодо використання засобів і методів розвитку їхньої творчої активності, тому обґрунтування фрормування творчості майбутніх фрахівців 3 фрізичної культури і спорту є актуальним. Вирішення цієї проблеми дасть змогу підвищити ефрективність усього навчально-виховного процесу в 3ВО, а цілеспрямована робота з розвитку творчості сприятиме набуттю знань, умінь і навичок у руховій сорері, підвищенню рівня розвитку фрізичної культури особистості, фрормуванню навичок і досвіду самостійної роботи студентів.

Формулювання цілей статті (постановка завдання). Основною метою нашої дослідницької роботи є теоретичне обґрунтування фрізичної культури як потужного чинника фрормування і розвитку творчого потенціалу особистості.

Виклад основного матеріалу дослідження. Система властивостей особистості, яка дає можливість творити, знаходити нові нестандартні рішення і діяти оригінально, є ії творчим потенціалом. Він включає в себе такі структурні компоненти: рефлексивний, мотиваційний, емоційний, вольовий, інтелектуальний, духовно-моральний. У таблиці 1 наведена загальна характеристика компонентів, які утворюють єдину цілісну структуру і становлять підґрунтя особистісного потенціалу людини [10].

Таблиця 1

Основні компоненти творчого потенціалу особистості

\begin{tabular}{|c|c|}
\hline $\begin{array}{l}\text { Компоненти } \\
\text { творчого } \\
\text { потенціалу } \\
\text { особистості }\end{array}$ & Загальна характеристика \\
\hline Рефрлексивний & $\begin{array}{l}\text { Здатність особистості відображати } \\
\text { результати власних дій, оцінювати } \\
\text { свої досягнення і недоліки, вносити } \\
\text { корективи в процес подальшої } \\
\text { діяльності. }\end{array}$ \\
\hline Мотиваційний & $\begin{array}{l}\text { Виражає рівень і своєрідність } \\
\text { інтересів і захоплень особистості, } \\
\text { зацікавленість і активність її участі } \\
\text { в творчій діяльності за домінуючої } \\
\text { ролі пізнавальної мотивації. } \\
\end{array}$ \\
\hline Емоційний & $\begin{array}{l}\text { Емоційне ставлення особистості } \\
\text { до процесу і результату творчої } \\
\text { діяльності, емоційний настрій до неї, } \\
\text { емоційно-образні характеристики } \\
\text { психіки. }\end{array}$ \\
\hline Вольовий & $\begin{array}{l}\text { Здатність особистості до необхідної } \\
\text { саморегуляції і самоконтролю, якості } \\
\text { уваги, самостійність до вольового } \\
\text { напруження, наполегливість у } \\
\text { досягненні мети творчої діяльності, } \\
\text { вимогливість до результату власної } \\
\text { творчості. } \\
\end{array}$ \\
\hline $\begin{array}{l}\text { Інтелектуаль- } \\
\text { ний }\end{array}$ & $\begin{array}{l}\text { Відображає оригінальність, гнучкість, } \\
\text { адаптованість, оперативність } \\
\text { мислення; легкість асоціацій; рівень } \\
\text { розвитку творчої уяви і спеціальних } \\
\text { здібностей. }\end{array}$ \\
\hline $\begin{array}{l}\text { Духовно- } \\
\text { моральний }\end{array}$ & $\begin{array}{l}\text { Здатність особистості розрізняти й } \\
\text { обирати справжні моральні цінності і } \\
\text { дотримуватися їх у своєму житті. Він } \\
€ \text { інтегруючим у структурі творчого } \\
\text { потенціалу особистості. }\end{array}$ \\
\hline
\end{tabular}


Згідно з визначеними компонентами алгоритм виховання творчості у майбутніх фрахівців з фрізичної культури і спорту буде таким.

Формування продуктивної діяльності. Першим або нижчим рівнем вважається репродуктивний або рівень відтворення. Він пов'язаний 3 процесами оволодіння навичками діяльності, 3 навчанням. Цей рівень передбачає повторення розроблених іншими людьми прийомів і дій, створення продукту за зразком. Наприклад, студент, який виконує комплекс рухових вправ за схемою, займається репродуктивною діяльністю. Необхідно навчати студентів прагнення до нового, вносити щось своє оригінальне в чужі схеми, розробки, тобто використовувати в репродуктивній діяльності елементи творчості, у такий спосіб збільшуючи соціальний досвід. На стадії первісного накопичення інфрормації народжується передчуття задуму, неясне очікування відкриття.

Більшість рухливих і спортивних ігор має великий потенціал фрізичних вправ, виконання яких вимагає перенесення наявних рухових навичок в ігрову ситуацію. Особливе значення має використання методу творчих завдань, що забезпечує розвиток творчості під час складання комбінацій орізичних вправ [9].

Формування рефрлексування. Сприяючи нагромадженню досвіду усвідомленої діяльності, рефлексія дає змогу людині повніше розкрити свою унікальність і індивідуальність та зробити процес творчого саморозвитку особистості студента більш цілеспрямованим і усвідомленим. Рівень розвитку рефлексійного компонента проявляється у ступені свідомих суджень особистості, в яких вона в процесі творчого саморозвитку намагається сорормулювати свою цінність, оцінити себе [12].

Формування мотивації до творчої діяльності передбачає орормування готовності студентів брати участь у процесі педагогічної діяльності визначати теми, проблеми, завдання, самостійно знаходити джерела інформації тощо. Результатом виступає не тільки реальний продукт, а й саморозкриття особистості. Результат вимагає оцінки і має бути орієнтований на корисність, потрібність створюваного продукту, тому схвалення є дуже важливим і сильним стимулом, що активізує творчість і сприяє розвитку творчих здібностей.

Формування емоційного компонента. Практична творча діяльність керується свідомістю і підсвідомістю. Часто поштовхом до народження задуму може бути якась незначна подія, випадкова зустріч, почута фрраза або побачений об'єкт. Кульмінаційним моментом творчого акту є натхнення. Людина в стані натхнення відчуває сплеск психічної і фрізичної енергії і насолоду процесом. 3 погляду психології натхнення супроводжується зміненим станом свідомості, коли людина творить, не помічаючи часу, голоду, втоми, іноді доводячи себе до фрізичного виснаження. Під його впливом продуктивність діяльності зростає в рази. Натхнення $€$ результатом наполегливої розумової роботи. Від захопленості творчою діяльністю залежить інтелектуальний розвиток людини.

Формування інтелектуального компонента творчої діяльності. Творча діяльність доступна кожній людині з нормальним розумовим розвитком. Але потреба в творчості, яка властива дітям, зберігається не у всіх дорослих. Причини цього найрізноманітніші: особливості виховання, обмеження суспільства, якому не потрібно занадто багато активних креатинів, інші. У зв'язку з тим, що в творчому навчанні немає заздалегідь запропонованого шляху вирішення, а проблема виникає в процесі роботи, в такому разі йдеться про розвиток так званого «дивергентного мислення». Воно передбачає наявність таких інтелектуальних здібностей, як гнучкість думки (здатність перемикатися з однієї ідеї на іншу), оригінальність (здатність висувати гіпотези, ідеї, які не регламентовані умовами діяльності), допитливість тощо.

Формування духовно-морального компонента творчої діяльності. Творча діяльність в освітньому процесі сприяє екстеріоризації особистістю нових, культурно зумовлених цінностей. Творча особистість педагога в цьому процесі виявляється часто вирішальним моментом у розвитку і формуванні творчих можливостей майбутніх фрахівців з фрізичної культури і спорту. Творчий рівень розвитку фрізичної культури особистості відображає глибоке розуміння і переконаність у практичній необхідності використання саме фрізичної культури, її соціально духовних цінностей для формування всебічно і гармонійно розвиненої особистості.

Формування вольового компонента творчої діяльності. Цей етап відрізняє високий рівень усвідомленості. На ньому відбувається осмислення і конкретизація ідеї - наукова теорія набуває чітких доказів, створюються схеми і план діяльності для реалізації конструкторського задуму. Формування вольового компонента може бути в двох формах: у фрормі скрупульозного аналізу виниклої ідеї, її планування та опрацювання різних варіантів і шляхів вирішення; в евристичній фрормі, коли накопичення інформації і роздуми над можливим ії̈ використанням раптово народжують оригінальну ідею. Власне, це останній етап творчості, який відбувається на рівні свідомості. А наступний етап - це вже практична діяльність.

Практична творча діяльність студента складається з таких видів діяльності: фрормулювання проблеми $\rightarrow$ постановка завдання $\rightarrow$ планування роботи $\rightarrow$ підбір методів виконання $\rightarrow$ захист своєї позиції $\rightarrow$ виконання проєкту $\rightarrow$ захист проєкту.

Основним методом розвитку творчої діяльності майбутніх фрахівців з фрізичної культури є метод 
творчих фрізкультурно-спортивних проєктів, в яких студенти можуть виступати одразу в декількох ролях, які наведено в табл. 2.

Таблиця 2

\section{Характеристика діяльності} згідно з творчою роллю студента

\begin{tabular}{|c|c|}
\hline $\begin{array}{c}\text { Творча роль } \\
\text { студента }\end{array}$ & Характеристика діяльності \\
\hline $\begin{array}{l}\text { Розроблювач } \\
\text { проєкту }\end{array}$ & $\begin{array}{l}\text { студенти використовують свої } \\
\text { професійні знання і вміння, } \\
\text { а також творчі здібності та } \\
\text { створюють відповідні програми } \\
\text { фрізкультурно-спортивних заходів } \\
\text { різного рівня }\end{array}$ \\
\hline Менеджер & $\begin{array}{l}\text { студенти організовують і } \\
\text { координують процес здійснення } \\
\text { програми, розробленої у } \\
\text { рамках проєкту, беруть участь в } \\
\text { організації та реалізації рекламної } \\
\text { кампанії }\end{array}$ \\
\hline $\begin{array}{l}\text { Безпосередній } \\
\text { учасник програми }\end{array}$ & $\begin{array}{l}\text { студенти беруть участь у заходах, } \\
\text { які заплановані проєктом } \\
\text { (змаганнях, іграх та інших } \\
\text { видах фрізкультурно-спортивної } \\
\text { діяльності) }\end{array}$ \\
\hline $\begin{array}{l}\text { Оцінювач } \\
\text { ефрективності } \\
\text { проєкту }\end{array}$ & $\begin{array}{l}\text { студенти аналізують } \\
\text { результативність проведеної } \\
\text { роботи за критеріями її соціальної } \\
\text { важливості, ціннісної значущості, } \\
\text { вкладу у фрормування здорового } \\
\text { способу життя та зміцнення } \\
\text { здоров'я учасників програми. }\end{array}$ \\
\hline
\end{tabular}

Виступаючи в таких різноманітних ролях, майбутні фрахівці з фрізичної культури і спорту забезпечують розвиток власних когнітивних компонентів творчого потенціалу особистості, зміцнення мотиваційних структур власного творчого потенціалу через включення в захоплюючі види змагальної активності; розвиток і зміцнення власного фрізичного розвитку; умінь і навичок здорового способу життя, умінь творчо застосовувати і використовувати свої можливості в спілкуванні, пізнанні, професійній діяльності; фрормування всіх компонентів творчого потенціалу особистості.

Висновки із цього дослідження і подальші перспективи в цьому напрямі. Фізична культура має великий потенціал для формування у студентів не тільки самостійного пошуку, а й досвіду творчої діяльності. Таким прикладом може служити метод творчих фрізкультурно-спортивних проєктів. Це спосіб організації самостійної діяльності майбутніх фрахівців з фрізичної культури і спорту із досягнення певного результату. Він орієнтований на інтерес, на творчу самореалізацію особистості, що розвивається, розвиток інтелектуальних і фізичних можливостей студента, його вольових якостей і творчих здібностей.

У навчально-виховному процесі ЗВО під час формування творчих здібностей студентів необ- хідно не тільки відтворювати ними на практиці отримані знання, а й вміти нестандартно реалізовувати їх у руховій сорері. Для того щоб майбутній фрахівець 3 фрізичної культури і спорту активно й творчо підходив до вирішення поставлених завдань, необхідно долати усталені стереотипи в навчанні і вихованні, розширювати арсенал засобів, методів і прийомів, які активізують мотивацію творчої діяльності студентів. А це висуває більш високі вимоги до професійної діяльності викладачів 3ВО.

\section{БІБЛІОГРАФІЧНИЙ СПИСОК:}

1. Барабанова В.Б. Философия в контексте фризической культуры. Успехи современного естествознания. 2011. № 6. С. 60-62.

2. Білогур В. Спорт як соціально-ціннісна й тілесно-духовна система. Versus. 2013. № 2. С. 68-73.

3. Столяров В.И. Философия фризической культуры и спорта. Книга І. Метафилософский анализ: ффилософрия ффизической культуры и спорта как особая фрилософская дисциплина. Москва : Изд-во Прочая научная литература, 2017. 446 с.

4. Гавалешко О.М. Інтеграція комунікативних та творчих компонентів у структурі самосвідомості особистості. Київ, 2001. 20 с.

5. Ермаков С.С. Физическая культура-основной инструмент культуры здоровья. Педагогика, психология и медико-биологические проблемы фризического воспитания и спорта. 2010. № 11. С. 31-33.

6. Зайченко І.В. Педагогіка : навчальний посібник. Київ : Освіта України, КНТ, 2008. 528 с.

7. Іващенко О.В., Худолій О.М. Творчі роботи в системі підготовки вчителя фрізичної культури. Теорія і методика фрізичного виховання. 2010. № 3. С. 7-10.

8. Ильин Е.П. Психология творчества, креативности, одарённости. Санкт-Петербург : Питер, 2004. $434 \mathrm{c}$.

9. Ротерс Т.Т. Формування духовної культури майбутніх учителів фрізичного виховання засобами музично-ритмічних занять. Педагогіка, психологія та медико-біологічні проблеми фрізичного виховання i спорту. 2005. № 10. С.58-65.

10. Рыжов В.В. Развитие творческого потенциала личности студентов средствами фризической культуры. Современные проблемы науки и образования. 2015. № 2-1. URL: http://www.scienceeducation.ru/ru/article/view?id=20839 (дата звернення: 10.06.2019).

11. Рыскулова М.Н. О компонентах процесса творческого саморазвития личности обучающегося. Педагогическое мастерство : материалы II Междунар. науч. конф. (г. Москва, декабрь 2012 г.). Москва : Буки-Веди, 2012. URL: https:// moluch.ru/conf/ped/archive/65/3141/ (дата звернення: 02.06.2019).

12. Сисоєва С.О. Проблема фрормування особистості, здатної до творчої самореалізації. Збірник наукових праць. Миколаїв : Вид-во МФ НАУКМА, 2000. № 7. C. 13-19.

13. Уланова С. Творча діяльність як смисложиттєва фрорма людської активності: європейська модель. Культура і сучасність, 2010. № 1. С. 5-9. 